FNG \& Bilim Tip Transplantasyon Dergisi 2016;1(2):88-91

doi: 10.5606/fng.transplantasyon.2016.015

\title{
Pankreas nakli
}

\section{Pancreas transplantation}

\author{
Feyzullah Güçlü, ${ }^{1}$ Emin Taşkıran ${ }^{2}$ \\ ${ }^{1} \dot{I} z$ mir Tepecik Eğitim ve Araştırma Hastanesi, Endokrinoloji Kliniği, İzmir, Türkiye \\ ${ }^{2} \dot{I} z m i r$ Tepecik Eğitim ve Araştırma Hastanesi, İç Hastalıkları Kliniği, İzmir, Türkiye
}

\begin{abstract}
öz
Tip 1 diyabetes mellitus patofizyolojisinde insülin sekrete eden beta hücrelerde tahribat ve lenfosit infiltrasyonu görülmektedir. Bunun sonucunda, azalan insülin sekresyonuna bağlı olarak kan şekeri düzeyini kontrol etmek zordur. 1966'da, Minnesota Üniversitesinde W.D. Kelly pankreas nakli ile tip 1 diyabetik bir hastada başarı sağlamıştır. Aynı üniversitede, 1978'de uygulama prosedürleri belirlenmiştir. 1980'de yeni cerrahi tekniklerin ve immünosüpresif tedavinin gerekliliği keşfedilmiştir. Son yıllarda, pankreas nakli prognozu daha iyidir ve uzun dönemli risklerde azalma görülmektedir. Nakilden bir yıl sonra, olguların \%95'i sağ kalmakta ve pankreas fonksiyonlarının \%80-85'i korunmaktadır.
\end{abstract}

Anahtar sözcükler: Endikasyonlar; pankreas nakli; prognoz.

\begin{abstract}
Destruction and lymphocyte infiltration of insulin secreting beta cells are observed in the pathogenesis of type 1 diabetes mellitus. As a result of this, it is challenging to control blood glucose level due to decreased insulin secretion. In 1966, W.D. Kelly achieved success in a type 1 diabetic patient with pancreas transplantation at Minnesota University. At the same university, application procedures were determined in 1978. In 1980, the requirement of new surgical techniques and immunosuppressive therapy was discovered. In recent years, prognosis of pancreas transplantation has improved and a decrease in long-term risks is observed. One year after transplantation, $95 \%$ of cases survive and $80 \%$ to $85 \%$ of pancreatic functions are preserved.

Keywords: Indications; pancreas transplantation; prognosis.
\end{abstract}

Tip 1 diyabetes mellitus'ta (DM) patofizyolojide insülin sekrete eden beta hücrelerde lenfositik infiltrasyon ve harabiyet görülmektedir. Bunun sonucunda, azalan insülin sekresyonuna bağlı kan şeker düzeyi kontrol edilemez. \%80-90 düzeyinde beta hücre hasarı oluşmasıyla hiperglisemi meydana gelir. Ekzojen insülin kullanımına gerek duyulur. Bu tedaviyle, katabolik süreç düzelir, ketoz önlenir, glisemik kontrol sağlanır, lipid ve protein metabolizması normale döner. Sonuç olarak; tip 1 DM patofizyolojisinde ana faktör otoimmünitedir. Genetik faktör yanında viral enfeksiyonlara bağlı olarak otoimmün yanıt tetiklenmektedir. Viral proteinlerin pankreas beta hücre benzerliği bu yanıtın oluşmasına neden olur. Yaklaşık olarak \%85 tip 1 DM'li hastada dolaşımda islet hücre antikorları vardır. İnsülin tedavisi verilmesi öncesinde çoğu olguda bu antikorların varlığı gösterilebilir. Beta hücrelerinde bulunan glutamik asit dekorboksilaz enzimine karşı gelişen anti-GAD (Glutamik asit dekarboksilaz antikorları) en sık bulunanıdır. ${ }^{[1]}$

Pankreas beta hücre fonksiyonlarında tamamen veya tama yakın kaybında, brittle diyabet oluşmaktadır. Özellikle bu olgularda sık hipoglisemi ve hiperglisemi atakları gözlenmektedir. Buna bağlı olarak da komplikasyon sıklığı artmaktadır. Sıklıkla retinopati, ateroskleroza bağlı oluşan değişiklikler ve böbrek yetmezliği ön plandadır. ${ }^{[1]}$

Pankreas nakliyle eksojen insülin kullanımına gerek kalmaz ve kan şekeri kontrolü sağlanacağından olası komplikasyonlardan 
korunmuş olunur. Pankreas nakli yapılan hastaların \%90', son dönem böbrek yetmezliği gelişmiş hastalardır. Bu hastalara nakil işlemi, böbrek nakliyle beraber yapilmaktadır. ${ }^{[2]}$

\section{Tarihçe}

Pankreas nakli hakkında deneysel çalışmalar insülinin keşfinden önce başlamıştır. 1891 yılında, köpeklerde pankreas ototransplantasyonunun cilt altına yapilmasıyla, pankreas dokusunun kaldırılmasından sonra diyabet önlenmiştir. Hayvanlarda intrasplenik nakil uygulamalarında, greft nekrozuna bağlı olarak başarı elde edilememiştir.

1916 y1lında ise insanda yapilan iki organ naklinde, greftlerin absorbe edildiği görülmüştür. 1893 yılında da İngiltere' de 15 yaşındaki bir olguya cilt altı pankreas nakli yapılmış, ancak başarı elde edilememiştir. Hayvan deneylerine rağmen, 1966 yılına kadar bu konuda başarı elde edilememiştir. 1966 yllında Minnesota Üniversitesinde W.D. Kelly pankreas nakli ile tip 1 diyabetik hastada başarı sağlamıştır. Yine aynı üniversitede, 1978 yllinda uygulama prosedürleri belirlenmiştir. 1980 yılında da yeni cerrahi teknikler ve immünosüpresif tedavi gerekliliği geliștirilmiștir. ${ }^{[3]}$ Bunu takiben, 1998 yılına kadar yaklaşık olarak 10.000 pankreatik nakil yapılmıştır.

\section{PANKREAS NAKLI ENDIKKASYONLARI}

American Diabetes Association (ADA) ve Dünya sağlık Örgütü (DSÖ) tarafından nakil yapılacak hastaların önerileri yayımlanmıştır. ${ }^{[4,5]}$

1. Pankreas nakli böbrek yetmezliği gelişmiş veya gelişme riski çok fazla olan tip 1 DM'li hastalarda, kronik insülin tedaviye alternatif olarak yapilabilir. Bu olgularda böbrek nakliyle eş zamanlı olarak yapılan pankreas nakli mortaliteyi anlamlı düzeyde artırmaz. Hatta böbrek naklinin sorunsuz devam etme süresini artırır. Bunun nedeni glisemik kontrolün sağlanması ve mikro- ve makrovasküler komplikasyonların ilerlemesinin yavaşlamasıdır. Hastaların medikal ve cerrahi riskleri ikili nakil yapılmasına uygun olmalidir.

2. Böbrek nakli için endikasyonu olmayan hastalarda, şu üç kriter mevcutsa yalnız pankreas nakli yapilabilir:
- Sık ve ağır metabolik komplikasyonların (hipoglisemi, akut hiperglisemi, diyabetik ketoasidoz) varlığı.

- Ekzojen insülin tedavisi ile klinik olarak kontrol edilmesi güç olan labil diyabet ve emosyonel sorunlarin bulunması.

- Yoğun insülin tedavisine rağmen akut komplikasyonların önlenememesi.

3. Pankreas adacık nakli, organ nakline göre teknik açıdan daha avantajlıdır. İnsülinsiz remisyon oranında artış sağlar. Bir yıllık sağkalım \%70 düzeyinde, beş yıllık sağkalım ise \%10 civarındadır. Ancak hastalarda immünosüpresif kullanımı gerektiğinden, bu konuda deneyimli merkezler tarafından yapilmalıdir.

\section{PANKREAS NAKLI KONTRENDIKASYONLARI}

1. Kanser öyküsü, pankreas adenomları ve insülinomalı hastalar

2. Tedavi edilmemiş enfeksiyon varlığı, düzeltilemeyen kalp yetmezliği

3. Kronik alkol kullanımı veya bağımlılığı

4. Psikiyatrik hastalıklar.

Obezite ve önemli diyabetik komplikasyon varlığında (ilerlemiş retinopati, nöropati, koroner arter hastalığı ve ekstremitede gangren vb.) pankreas nakli yapılması kontrendikedir.

Pankreas naklinde, kadavradan veya canl dokudan alınan doku kullanılır. Aynı anda böbrek nakli ve pankreas nakli yapilan uygulama dışında, önce böbrek nakli yapılmış hastalara, kadavra ya da beyin ölümü gerçekleşmiş olgudan alınan pankreas dokusu nakli şeklinde de yapılabilir (\%15). Böbrek ve pankreas naklinin birlikte yapıldığı durumda, pankreas dokusunun kadavra ya da beyin ölümü gerçekleşmiş vericiden, böbrek dokusunun da canlı hastadan alınması, her iki dokununda canlı olgudan alınarak yapılan nakle kıyasla greft fonksiyonlarında düşük oranda gecikme görülür. ${ }^{[6]}$ Yüzde 10 olguda da diyabete bağlı değişken sorunlar nedeniyle sadece pankreas nakli yapılan hastalardir bu hastalarda renal fonksiyonlarda sorun yoktur. Alternatif yeni tedavi uygulamada ise diyabeti düzeltmek amaciyla islet nakli üzerinde yapılan deneysel çalışmalar vardır. 


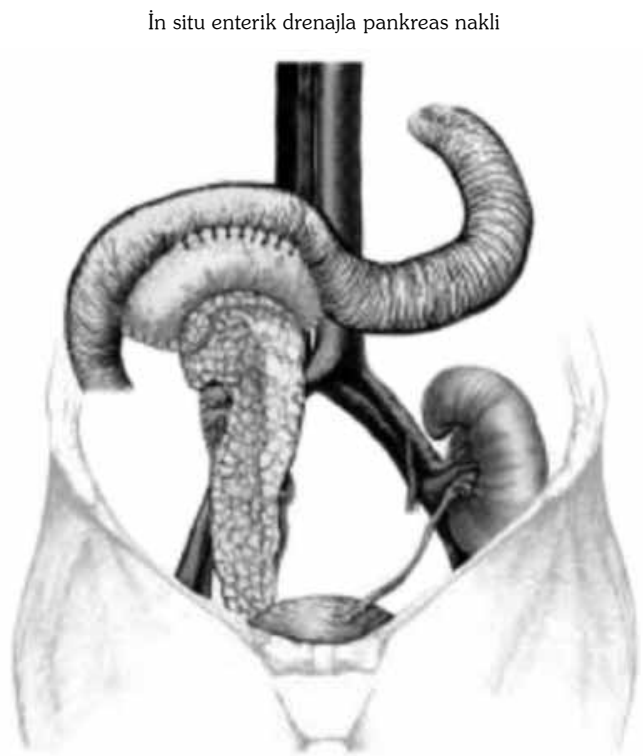

Şekil 1. Pankreas naklinin anatomik illüstrasyonu.

Ancak bu uygulamalardaki bilgi, pankreas nakli kadar yeterli düzeyde değildir.

Pankreas dokusunun nakil yapilana kadar korunması ve pankreas dokudaki donör kanının değiştirilmesi için buzla soğutulmuş solüsyon içerisinde bekletilmesi gereklidir. Wisconsin Üniversitesi solüsyonu veya Viaspan kullanılır ve implantasyon yapılacağı zamana kadar bu solüsyonda tutulur. Yaklaşık olarak 30 saate kadar koruyucudur. ${ }^{[7]}$

Pankreas naklinde kullanılan çeşitli tekniklerdeki endişeler, venöz drenajın sistemik dolaşıma veya portal ven içerisine olup olmamasıdır. ${ }^{[1]}$ Diğer bir uygulamada da ekzokrin sekresyonun bağırsak içerisine veya mesane içerisine yapılmasıdır. ${ }^{[8]} \mathrm{Bu}$ nakillerde ilk uygulamlarda greft dokusunda görülen pankreatit ve idrar kaçağı sorunu geliştirilen tekniklerle, doku reddi (rejeksiyonu) de immünosüpesif tedaviyle önlenmiştir (Şekil 1).

\section{Komplikasyonlar}

Sıklıkla komplikasyonlar ameliyatı takip eder, tromboz, pankreatit, enfeksiyon, kanama ve doku reddi şeklindedir. Doku reddi hastanın yaşamı sırasında herhangi bir zamanda oluşabilir. Sonuç olarak yabancı dokunun immün sistem tarafından reddi mümkün olabilir. $\mathrm{Bu}$ durum ciddi bir tablo olup, hemen tedavi edilmesi gereklidir. Bu durumu önlemek için immünsüpresif tedavi rejimleri kullanılmaktadır. Bunun için kullanılan tedavi yaklaşımları, siklosporin, azotioprin ve kortikosteroidlerdir. Doku reddinin tekrarlaması ise yine yaşamın herhangi bir zamanında olabilmektedir. Zaman içerisinde immünosüpresif tedavi dozajları modifiye edilerek doku reddinden korunma yoluna gidilir. Bazende siklosporin yerine takrolimus ve azotioprin yerine mikofenalat mofetil kullanilır. ${ }^{[2]}$

\section{Prognoz}

Son yıllarda pankreas naklinin prognozu çok daha iyidir. Uzun dönemde oluşacak risklerde azalma görülmektedir. Nakil sonrasında, bir yılda \%95 oranında olgu sağ kalmakta ve pankreas fonksiyonları \%80-85 oranında korunmaktadır. Nakil sonrasında yaşam boyunca immünosüpresyon tedavisi alınması gereklidir. Bu tedaviye bağlı olarak da çeşitli enfeksiyonlar ${ }^{[9]}$ ve kanser görülebilir. İmmünosüpresif tedavide sıklıkla steroid kullanılmaktadır ve bu tedavinin diğer tedavi seçenekleri ile değiştirilmesi gerekliliği tam olarak açık değildir. ${ }^{[10]}$ Diğer yandan da kullanılan immünosüpresif tedaviye bağlı oluşabilecek diyabet varlığ1 da diğer bir sorundur.

\section{Çıkar çakışması beyanı}

Yazarlar bu yazının hazırlanması ve yayınlanması aşamasında herhangi bir çıkar çakışması olmadığını beyan etmişlerdir.

\section{Finansman}

Yazarlar bu yazının araştırma ve yazarlık sürecinde herhangi bir finansal destek almadıklarını beyan etmişlerdir.

\section{KAYNAKLAR}

1. Kronenberg HM, Melmed S, Polonosky KS, Larsen PR. Tip 1 diabetes (insulin dependent). Williams Textbook of Endocrinology, 11nd ed. Chichester: Wiley; 2008.

2. Gruessner AC, Sutherland DE. Pancreas transplant outcomes for United States (US) and non-US cases as reported to the United Network for Organ Sharing (UNOS) and the International Pancreas Transplant Registry (IPTR) as of June 2004. Clin Transplant 2005;19:433-55

3. Aathira R, Jain V. Advances in management of type 1 diabetes mellitus. Advances in management of type 1 diabetes mellitus. World J Diabetes 2014;5:689-96.

4. Waki K, Kadowaki T. An analysis of long-term survival from the OPTN/UNOS Pancreas Transplant Registry. Clin Transpl 2007:9-17.

5. Ryan EA, Paty BW, Senior PA, Bigam D, Alfadhli E, Kneteman NM, et al. Five-year follow-up after clinical islet transplantation. Diabetes 2005;54:2060-9. 
6. Farney AC, Cho E, Schweitzer EJ, Dunkin B, Philosophe B, Colonna J, et al. Simultaneous cadaver pancreas living-donor kidney transplantation: a new approach for the type 1 diabetic uremic patient. Ann Surg 2000;232:696-703.

7. Iwanaga $\mathrm{Y}$, Sutherland DE, Harmon JV, Papas KK. Pancreas preservation for pancreas and islet transplantation. Curr Opin Organ Transplant 2008;13:135-41.

8. Kobayashi E, Kamada N, Toyama N, Delriviere L,
Goto S, Enosawa S, et al. Successful methods of pancreas transplantation in the rat using a cuff technique. Aust N Z J Surg 1994;64:491-3.

9. Fishman JA, Rubin RH. Infection in organ-transplant recipients. N Engl J Med 1998;338:1741-51.

10. Montero N, Webster AC, Royuela A, Zamora J, Crespo Barrio M, Pascual J. Steroid avoidance or withdrawal for pancreas and pancreas with kidney transplant recipients. Cochrane Database Syst Rev 2014;9:7669. 